\title{
POLSKIE ARCHIWUM KARMELITÓW BOSYCH: HISTORIA, WYBITNE POSTACI, METODA I ZBIORY
}

Chociaż ludzką codzienność pomagają porządkować liczne dyscypliny naukowe z matematyką, królową nauk, na czele, to tylko do historii przylgnęło określenie, że jest nauczycielką życia. Cyceron pisał: „Historia est testis temporum, lux veritatis, vita memoriae, magistra vitae, nuntia vetustatis - Historia jest świadkiem czasów, światłem prawdy, życiem przeszłości, nauczycielką życia, głosicielką tradycji” ${ }^{\prime}$. Z równie wielkim szacunkiem wypowiadał się o niej Jan Długosz: „Antiquitatis enim et historiae et rerum forisque gestarum notitia virtutis parens et vitae magistra a sapientibus habita est - Znajomość bowiem starożytności i historii i czynów dokonanych na wojnie jest uważana przez ludzi mądrych za rodzicielkę i nauczycielkę życia”".

Historia jako dyscyplina naukowa nie miałaby zbyt wiele do powiedzenia, gdyby nie istnienie materialnych nośników minionych wydarzeń: naskalnych rysunków, papirusów, glinianych tabliczek, pergaminów, książek, listów itp. Wszystkie te artefakty zbiera i zabezpiecza archiwistyka. Pełni ona względem historii funkcję służebną, dostarczając wiedzy, dzięki której możliwe staje się poszukiwanie mądrości życia.

Pomimo strat, jakie przynoszą pamiątkom przeszłości wojny, przewroty, wypaczone ideologie, a nawet zwykła ludzka niefrasobliwość, nigdy nie brakowało i z pewnością nie zabraknie osób troszczących się o cenne dziedzictwo minionych pokoleń. To dzięki cierpliwej pracy archiwistów, wspieranych nowoczesnymi technikami konserwatorskimi, poszczególne narody wciąż mogą czerpać ze źródeł własnej tożsamości, ubogacając w ten sposób doświadczenie całej ludzkiej społeczności.

Dicta. Zbiór łacińskich sentencji, przysłów, zwrotów, powiedzeń, red. Cz. Michalunio, Kraków 2010, s. 224.

2 Tamże, s. 49. 


\section{ARCA TRIUM CLAVIUM}

Swój niepowtarzalny wkład w zabezpieczenie i udostępnianie nośników wiedzy o przeszłości mają także karmelici bosi. Od czasu ich przybycia do krakowskiego grodu nad Wisłą w sierpniu 1604 roku dzieje karmelitańskiego zakonu splotły się na stałe z historią polskiego narodu. Oficjalne relacje z królami, urzędnikami państwowymi, biskupami, właścicielami ziem oraz dobroczyńcami owocowały powiększającym się z każdą dekadą zbiorem ważnych pism, bez których niemożliwe było fundowanie klasztorów i podejmowanie przez zakonników właściwej im misji.

Ważne dokumenty, księgi i precjoza składano w arca trium clavium - skrzyni o trzech kluczach ${ }^{3}$. Pełniła ona funkcję pierwotnego archiwum domowego. Zamykano ją trzema różnymi kluczami, z których jeden posiadał przeor, a dwa kolejne dyskreci, czyli zakonnicy pełniący posługę doradców przełożonego klasztoru. Otwarcie skrzyni było możliwe tylko w obecności wszystkich trzech.

Pierwsze klasztory karmelitów bosych w Polsce należały do Kongregacji Włoskiej pw. św. Eliasza. Jej instrukcje ${ }^{4}$ normowały sposób gromadzenia i przechowywania dokumentów. Określały, że w archiwum domowym powinny być złożone urzędowe księgi własne: kroniki klasztorne, księgi wizyt generalskich i prowincjalskich, księgi dóbr klasztoru, księgi dochodów, rozchodów i obligacji mszalnych, księgi zmarłych zakonników z krótkimi biogramami, księgi profesji zakonnych, księgi z informacjami o przyjmowanych nowicjuszach oraz akta osobiste zakonników, czyli personalia. W archiwum przechowywano również dwa kopiariusze przeznaczone do wpisywania akt kapituł i definitoriów generalnych oraz kapituł i definitoriów prowincjalnych. Kopiariusze te uwierzytelniał prowincjał w czasie wizyt kanonicznych.

Z ksiagg drukowanych archiwum miało posiadać Konstytucje zakonu, ordynarium, manuale, instrukcje, kalendarze i Privilegia Fratrum Discalceatorum wydane w Rzymie w 1617 roku. Ponadto składać w nim należało pisma o charakterze publicznym: dokumenty, breve apostolskie, testamenty, kontrakty kupna i sprzedaży, inskrypcje, cesje, oblaty itp.

Instrukcje określały także zakres odpowiedzialności przeorów za domowe archiwa, powierzając im zadanie archiwistów. Na przeora klasztoru obejmującego urząd przełożonego nakładały obowiązek sporządzenia inwentarza skrzyni o trzech kluczach. Dokument taki zawierał dokładny spis zawartości archiwum oraz przedmiotów i sum pieniężnych, jakie się w nim znajdowały. Archiwum domowe było zatem sprawdzane regularnie co trzy lata.

Do naszych czasów przetrwała tylko jedna z karmelitańskich skrzyń o trzech kluczach. Można ją zobaczyć w przyklasztornym muzeum w Czernej. Niektóre klasztory posiadały skrzynie dwukluczowe.

4 Instructiones Fratrum Discalceatorum Congregationis S. Eliae Ordinis Beatissimae Virginis Mariae de Monte Carmelo, Romae 1635, s. 119-122. 
Jeśli któryś z klasztorów był siedzibą prowincjała, to instrukcje polecały zorganizowanie oddzielnego od archiwum domowego miejsca, w którym składać miano dokumentację prowincjalną dotyczącą poszczególnych konwentów. Drzwi do tego pomieszczenia zamykane były na dwa klucze, z których jeden posiadał prowincjał, a drugi przeor.

Z biegiem czasu zasób domowych archiwów znacznie się zwiększył i niemożliwe stało się deponowanie licznych dokumentów i ksiąg w jednej skrzyni. Na archiwum klasztoru zaczęto więc przeznaczać oddzielne pomieszczenie, powierzając pieczę nad nim przełożonemu domu. Było to bez wątpienia najbardziej strzeżone miejsce w obrębie klasztoru, do którego dostęp miało niewielu zakonników, nie wspominając już o osobach świeckich. Chociaż czasami zdarzały się drobne lub poważniejsze niedociągnięcia $w$ trosce $o$ archiwa, $w$ większości przypadków postępowano $z$ należytą odpowiedzialnością, do czego obligowały nie tylko ogólnozakonne instrukcje, ale także zarządzenia definitorium prowincjalnego.

Za przykład troski o zabezpieczenie domowego archiwum może posłużyć postępowanie o. Alfonsa Mazurka, przeora klasztoru w Czernej. Pod datą 13 sierpnia 1934 roku odnotował w prywatnej kronice: „Z Krakowa przyjeżdżają o. Kanty, p. Russiak - urzędnik archiwów państwowych w Wilnie i Jerzy Langman, aby w naszym archiwum poszukać pewnych dokumentów co do Litwy i Ostrej Bramy. Dokumenty te im pokazałem, ale do archiwum nie wpuściłem"s. Natomiast w oficjalnej kronice klasztoru pod datą 26 lutego 1940 roku napisał:

Z Krakowa sprowadziliśmy pana Kazimierza Kuzyka, fotografa, celem poczynienia zdjęć fotograficznych tak klasztoru i okolicy, jak i ważniejszych dokumentów $z$ naszego archiwum, a przede wszystkim aktu fundacyjnego. Zdjęcia te potrzebne są nam do projektowanego druku widokówek lub do zamierzonej broszury o naszym klasztorze. Nadto, w ten sposób uratuje się od zagłady w tych niepewnych czasach jeżeli nie oryginał, to przynajmniej fotograficzne odbitki cenniejszych dokumentów, a osobliwie aktu fundacyjnego. Ten fotograf robił już takie zdjęcia zeszłego roku. Zawód swój i pracę wykonuje bardzo gustownie i artystycznie. Zdjęcia te wszystkie zbieramy w specjalnych albumach przechowywanych w archiwum, jako dokument historyczny dla potomności ${ }^{6}$.

A. MazureK, Kronika własna. Część V z lat 1930-1944, AKPZKB, sygn. AAM 7, s. 100.

Kronika klaszton OO. Karmelitów Bosych w Czemy z lat 1938-1953, AKPZKB, sygn. AKC 6, s. $119-120$. 


\section{DZIEje KLASZTORNYCH ARCHIWóW}

Minione wieki nie były zbyt łaskawe dla karmelitańskich archiwów. Większość klasztorów została ufundowana na wschodnich ziemiach Rzeczpospolitej, które na skutek licznych wojen nasza Ojczyzna utraciła. Kasaty konwentów i częste pożary dopełniły niszczycielskiego dzieła. Trzeba obiektywnie stwierdzić, że w stosunku do liczby fundacji i podejmowanych przez zakonników na przestrzeni kilku wieków dzieł ilość archiwaliów, jakie dzisiaj posiadamy, jest niewielka. Warto więc pokrótce prześledzić, co się z nimi stało ${ }^{7}$.

\section{Archiwum klasztoru pw. Niepokalanego Poczęcia NMP w Krakowie}

Klasztor pw. Niepokalanego Poczęcia NMP przy ul. Kopernika (obecnie szpital św. Łazarza), ufundowany w roku 1605, jest najstarszą fundacją karmelitów bosych na ziemiach polskich. Posiadał najbogatsze archiwum ze wszystkich. Do dzisiaj przetrwały tylko szczątki tej obszernej niegdyś kolekcji klasztornych ksiag i dokumentów. Gdy w 1787 roku na polecenie Michała Poniatowskiego, prymasa Polski, klasztor został przeznaczony na szpital miejski, zakonnicy przenieśli archiwum do drugiego krakowskiego klasztoru, pw. św.św. Michała i Józefa. Po jego kasacie przez rząd austriacki w 1797 roku archiwum podzielono na dwa zbiory. Jeden powędrował do lubelskiego konwentu pw. Matki Bożej Szkaplerznej i spłonął tam w pożarze w 1803 roku. Drugi przewieziono do klasztoru pw. św. Eliasza w Czernej, jednak do naszych czasów dotrwało z niego zaledwie kilkanaście pozycji. Do nich dołączono akta klasztoru wybudowanego na początku XX wieku przy ul. Rakowickiej, będącego wznowieniem pierwszej fundacji przy ul. Kopernika.

\section{Archiwum klasztoru pw. Matki Bożej Szkaplerznej w Lublinie}

Klasztor ten, ufundowany w 1610 roku, pełnił kilka ważnych funkcji: był domem studiów filozoficznych, siedzibą prowincjała, a także miejscem publicznych dysput $z$ arianami. Posiadał zatem bogate zbiory złożone w dwóch archiwach: domowym i prowincji. Archiwum domowe oprócz urzędowych ksiag własnych i akt personalnych zawierało bogate zbiory akt prawnych. W połowie XVII wieku siedziba prowincjała została przeniesiona do klasztoru św.św. Michała i Józefa w Krakowie. Wraz z nim powędrowało tam archiwum prowincji oraz część dokumentacji z archiwum domowego. Zbiór ten spłonął w pożarze klasztoru krakowskiego w 1763 roku. Pozostałą część archiwum klasztoru lubelskiego spotkał podobny los: spłonęła w 1803 roku.

Dokładne dane w tej kwestii odtworzył z różnych archiwalnych źródeł o. BENIGNus WANAT i opublikował w dwutomowym dziele: Katalog Archiwum Krakowskiej Prowincji Karmelitów Bosych pw. Ducha Świętego w Czernej, Kuria Krakowskiej Prowincji Karmelitów Bosych, t. 1, Kraków 1998, t. 2, Kraków 1999. 


\section{Archiwum klasztoru pw. św. Michała Archanioła we Lwowie}

Obecność karmelitów bosych we Lwowie datuje się od 1613 roku. Klasztor pw. św. Michała Archanioła przeznaczony był przez definitorium generalne na seminarium misyjne, a później na dom formacyjny profesatu. W 1784 roku zakonnicy zostali usunięci ze Lwowa przez władze austriackie w ramach kasaty klasztorów i przenieśli się do Zagórza. Zbiór klasztornego archiwum uległ wówczas rozproszeniu, o czym świadczy fakt, że jego pozostałości znajdują się w kilku różnych bibliotekach. W latach 1933-1939 karmelici wybudowali we Lwowie na Persenkówce nowy klasztor pw. Matki Bożej Szkaplerznej. W 1946 roku opuścili go z powodu przymusowej repatriacji. Niewielki zbiór archiwaliów z tego krótkiego okresu znajduje się obecnie w Archiwum Prowincji.

\section{Archiwum klasztoru pw. św.św. Michała i Józefa w Krakowie}

Wybudowany w latach 1611-1637, był drugim klasztorem zakonu w obrębie murów miejskich Krakowa. Mieściło się w nim kolegium teologiczne, a przez pewien czas siedziba prowincjała. Posiadał więc bogate archiwum domowe i archiwum prowincjalne. Część tych zbiorów spłonęła w pożarze w 1763 roku. Po kasacie klasztoru przez rząd austriacki w 1797 roku archiwum podzielono na dwa zbiory. Jeden powędrował do lubelskiego konwentu pw. Matki Bożej Szkaplerznej, a drugi przewieziono do klasztoru pw. św. Eliasza w Czernej. O losach tych zbiorów wspomniano powyżej, przy dziejach archiwum klasztoru pw. Niepokalanego Poczęcia NMP w Krakowie.

\section{Archiwum klasztoru pw. św. Józefa w Poznaniu}

Ufundowany w 1618 roku klasztor pozostawał w rękach zakonu do roku 1801, kiedy to na mocy decyzji króla pruskiego Fryderyka Wilhelma uległ kasacie. Odzyskano go w 1945 roku w stanie całkowitej ruiny i z biegiem lat odbudowano. Informacje pozyskane z różnych źródeł świadczą, że archiwum poznańskie było dość duże. W klasztorze mieściło się przez pewien czas kolegium filozoficzne. Największe straty archiwum poniosło w czasie najazdów szwedzkich. Niektóre archiwalia spłonęły w pożarze, inne dostały się w ręce Szwedów. Większą część zdołano jednak zabezpieczyć i ocalić. Po kasacie klasztoru część zbioru przewieziono do Warszawy, a część do Zakrzewa. $Z$ biegiem lat zbiory te uległy rozproszeniu. Nieliczne pozostałości znajdują się obecnie w Państwowym Archiwum w Poznaniu. Dokumenty klasztoru poznańskiego, które znajdowały się w archiwum prowincjalnym w Krakowie, w klasztorze św.św. Michała i Józefa, spłonęły podczas pożaru tego klasztoru.

\section{Archiwum klasztoru pw. św. Teresy od Jezusa w Przemyślu}

Klasztor przemyski, wybudowany w latach 1623-1630, pełnił rozliczne funkcje: domu nowicjackiego, profesatu i kolegium filozoficznego. W 1784 roku dekretem au- 
striackiego cesarza Józefa II został przekazany duchowieństwu greckokatolickiemu. Do karmelitów bosych powrócił w 1946 roku. Archiwum tego klasztoru zaginęło bez śladu. Przypuszcza się, że po eksmisji zakonników przez władze austriackie przeniesione zostało do Zagórza. Po likwidacji zaś konwentu zagórskiego część zbioru uległa rozproszeniu, a część przejęła Biblioteka Ossolineum we Lwowie. Archiwum Prowincji posiada jedynie dokumenty klasztoru od czasu jego rewindykacji w 1946 roku.

\section{Archiwum klasztoru pw. św. Teresy od Jezusa w Wilnie}

Klasztor wileński ufundowany w 1626 roku należał od 1731 roku do prowincji litewskiej pw. św. Kazimierza. Mieściła się w nim kuria prowincjalna i dom studiów. Klasztor został skasowany dekretem carskim w 1844 roku. Archiwum Prowincji Litewskiej, które prawdopodobnie znajdowało się w Wilnie, nie przetrwało do naszych czasów. Nie wiemy też, jakie były jego losy. Archiwum klasztoru wileńskiego uległo rozproszeniu i obecnie znajduje się w kilku różnych bibliotekach. Przez krótki czas, w latach 1931-1948, klasztor ponownie był w rękach karmelitów bosych. Archiwum Prowincji posiada dokumenty z tego właśnie okresu.

\section{Archiwum klasztoru pw. św. Eliasza w Czernej}

Wzniesiony w latach 1629-1640 jako erem, klasztor czerneński oparł się kasatom i zawieruchom wojennym. Szczyci się ciągłością życia zakonnego od czasu fundacji, dzięki czemu posiada bogate archiwum. Obejmuje ono archiwalia od wieku XV aż po XX. Nie znaczy to jednak, że zbiór jest kompletny. Obok licznych rękopisów i oryginalnych dokumentów do naszych czasów nie dotrwały kroniki klasztoru. Te, które obecnie posiadamy, rozpoczynają się od 1880 roku. Los zaginionych kronik nie jest znany.

\section{Archiwum klasztoru pw. Niepokalanego Poczęcia NMP w Berdyczowie}

Początki tego klasztoru przypadają na rok $1630 . Z$ powodu prowadzonej przy nim różnorodnej działalności - sanktuaryjnej, duszpasterskiej, naukowej i wydawniczej - posiadał on na przełomie XVIII i XIX wieku najbogatsze archiwum ze wszystkich ówczesnych klasztorów. Został skasowany w 1866 roku decyzją urzędu carskiego. Zakonnicy odzyskali go na krótko w 1918 roku, a na pobyt stały powrócili dopiero w 1991 roku. Losy archiwum od czasu kasaty nie są znane, podobnie jak losy dokumentów, które w 1925 roku przekazano Radzieckiej Akademii Nauk, gdy klasztor przejęły komunistyczne władze Związku Radzieckiego. 


\section{Archiwum klasztoru pw. Chrystusa Zbawiciela w Wiśniczu}

Klasztor ten, ufundowany w roku 1622 , był przez krótki czas domem nowicjatu i kolegium teologicznego. Został skasowany dekretem cesarza Józefa II w 1783 roku. Przypuszcza się, że archiwum klasztoru było skromne. Podczas kasaty uległo rozproszeniu i znalazło się w rękach prywatnych. $Z$ biegiem czasu część archiwaliów różnymi drogami dotarła do Biblioteki Ossolineum we Lwowie oraz Biblioteki Państwowej Akademii Nauk w Krakowie.

\section{Archiwum klasztoru pw. Wniebowzięcia NMP i św. Józefa w Warszawie}

Pierwsi karmelici bosi zamieszkali w Warszawie w 1639 roku. Tamtejszy klasztor na Krakowskiem Przedmieściu przeznaczony był na kolegium filozoficzno-teologiczne. Zakonnicy pełnili także funkcję kierowników duchowych wobec dworu królewskiego. Konwent został skasowany dekretem cara Aleksandra II w 1864 roku. Przypuszcza się, że wspólnota warszawska miała dość bogate archiwum, które jednak uległo rozproszeniu i zniszczeniu w czasie kasaty. Nieliczne ocalałe jednostki znajdują się obecnie w Archiwum Archidiecezji Warszawskiej.

\section{Archiwum klasztoru pw. św. Michała Archanioła w Wiśniowcu}

Klasztor ufundowany w 1644 roku uległ kasacie decyzją władz carskich w 1832 roku. Opuszczając go, zakonnicy przekazali księgi parafialne do urzędu parafialnego w Starym Wiśniowcu, a własne archiwum zabrali do Berdyczowa. Dzięki temu ocalało kilka jednostek z tego zbioru. Los pozostałych nie jest znany. W 1931 roku karmelici bosi powrócili do zniszczonego klasztoru, który w 1944 roku uległ całkowitemu spaleniu. W pożarze zniszczone zostało niewielkie domowe archiwum.

\section{Archiwum klasztoru pw. Zwiastowania NMP w Zagórzu}

Fundacja w Zagórzu datuje się na 1700 rok. Klasztor przeznaczony był na dom modlitwy i pracy ewangelicznej wśród okolicznych mieszkańców. Posiadał niewielkie archiwum, które spłonęło w pożarze klasztoru w 1822 roku. Ocalałe fragmenty tego zbioru znajdują się obecnie w Wojewódzkim Archiwum Państwowym w Krakowie na Wawelu.

\section{Archiwum klasztoru pw. Matki Bożej Szkaplerznej w Miadziole}

Karmelici bosi osiedlili się w Miadziole w 1754 roku. Działalność duszpasterską prowadzili do roku 1832, kiedy to klasztor został skasowany decyzją władz carskich. Archiwum domowe uległo rozproszeniu i zniszczeniu w czasie kasaty. Zakonnicy powrócili do Miadzioła w 1927 roku. Niewielkie archiwum z tego okresu zostało przez nich ukryte około 1949 roku w murach kościoła, zanim władze radzieckie uwięzi- 
ły tamtejszą wspólnotę. Kolejny powrót do Miadzioła nastąpił w 1990 roku. Dzięki szkicom, jakie w latach 60. XX wieku wykonał o. Jakobin Filek, jeden z ostatnich zakonników opuszczających Miadzioł po drugiej wojnie światowej, skrytki z archiwaliami udało się odnaleźć w 2018 roku. Wydobyte z nich księgi oraz relikwie stanowią obecnie własność miadziolskiej wspólnoty.

\section{Archiwum klasztoru pw. św. Józefa w Wadowicach}

Przybycie zakonników do Wadowic nastąpiło w 1892 roku. Pomimo dwóch wojen światowych archiwum klasztoru zachowało się w całości. Część domowego zbioru oraz archiwum Prywatnego Gimnazjum Karmelitów Bosych zarchiwizował o. Benignus Wanat w latach 60. XX wieku. W 2016 roku kapituła domowa konwentu wadowickiego przekazała do Archiwum Prowincji pozostałą część archiwum domowego, którym do śmierci opiekował się zasłużony historyk o. Honorat Gil. Dokumenty te zostały zarchiwizowane rok później.

\section{Archiwa pozostałych klasztorów}

Archiwa domowe klasztorów w Kamieńcu Podolskim, Głębokiem, Zakrzewie, Gudohajach, Poszumieniu i Taganrogu nie zachowały się do naszych czasów. Nie znamy też ich losów.

\section{WYBitne POSTACI}

Kasaty i pożary klasztorów, a także wojenne zawieruchy nie sprzyjały stabilności zakonnego życia. Polski karmelita bosy z przełomu XVII i XVIII wieku nazywany został przez jednego $z$ historyków homo viator - człowiekiem w drodze ${ }^{8}$. Konieczność częstego przemieszczania się z jednego miejsca do innego, co wiązało się z przewożeniem ocalałego dobytku, negatywnie odbiła się na karmelitańskich zbiorach archiwalnych. Pomimo takiego stanu rzeczy podejmowano liczne starania o gruntowne uporządkowanie i skodyfikowanie akt.

\section{O. Wawrzyniec od Najświętszej Maryi Panny (zm. 1682)}

Był pierwszym karmelitą bosym, który w sposób fachowy uporządkował archiwa w kilku klasztorach: Iwowskim, czerneńskim, wiśnickim i warszawskim. Historia przekazała nam niewiele informacji o jego osobie ${ }^{9}$. Nie wiemy, skąd pochodził. W 1648 roku otrzymał z rąk sufragana krakowskiego Alberta Lipnickiego tonsurę

Cz. GrL, Karmelita - Homo viator w XVII i XVIII w., „Nasza Przeszłośc” 109 (2008), s. 303-315.

K. FurmaniK, Księga zmarlych karmelitów bosych w Polsce, na Litwie i Rusi 1607-1998, t. I/1-2, Kuria Krakowskiej Prowincji Karmelitów Bosych, Kraków 2002, s. 246; B. Wanat, Katalog Archiwum Krakowskiej Prowincji Karmelitów Bosych pw. Ducha Świętego w Czemej, t. 1, s. 169. 
i cztery pierwsze święcenia. W tym też roku przyjął święcenia subdiakonatu, a dwa lata później, w roku 1650, diakonat. W 1653 roku został wyświęcony na kapłana. Pełniąc posługę przeora we Lwowie, a później w Warszawie, angażował się w troskę o całokształt życia powierzonych mu wspólnot. To pochłaniające niemało energii zadanie nie przeszkadzało mu jednak realizować osobistych zainteresowań, które skupiały się wokół archiwistyki. Można powiedzieć, że większość zakonnego życia spędził na porządkowaniu klasztornych archiwów. Praca ta polegała przede wszystkim na sporządzaniu kopiariuszy, regesów praw i ich kodyfikowaniu. Dla tych cennych dokumentów starał się o dobre zabezpieczenie. Archiwum klasztoru lwowskiego złożono w żelaznej skrzyni gdańskiej z kilkoma zamkami. Na kopiariuszach, które wychodziły spod jego ręki, wyraźnie zaznaczał, że nie wolno ich wypożyczać na zewnątrz: „Iste liber non facile extradatur extra conventum ad manus externorum propter rationes certas easque non contemmentes" ${ }^{10}$. Zmarł w 1682 roku w klasztorze przemyskim.

\section{O. Jan Kanty Osierda (1878-1948)}

Chociaż w minionych wiekach spora liczba karmelitańskich ksiąg i dokumentów uległa zniszczeniu, to jednak nie wszystko przepadło bezpowrotnie. Różnymi drogami do rąk prywatnych i państwowych bibliotek dostały się ważne dla historii polskich karmelitów bosych archiwalia. Ponieważ ich powrót do zakonnego archiwum nie był możliwy, misji przeglądnięcia i przepisania tych zasobów podjął się o. Jan Kanty Osierda ${ }^{11}$. Naukowe kwerendy w połączeniu z ogromną cierpliwością tego zakonnika zaowocowały cennymi tekstami powstałymi podczas setek godzin spędzonych w bibliotekach i archiwach Polski międzywojennej.

Alojzy Osierda urodził się 22 maja 1878 roku w Kozach koło Kęt. Nowicjat w Czernej rozpoczął obłóczynami 24 sierpnia 1898 roku. Otrzymał wówczas imię Jan Kanty od św. Naszej Matki Teresy. Profesję uroczystą złożył 24 sierpnia 1901 roku, a święcenia kapłańskie otrzymał 3 lipca 1904. Posługę zakonno-kapłańską spełniał w kilku klasztorach: czerneńskim, wadowickim, krakowskim, lubelskim i przemyskim. W tym ostatnim zmarł w dniu 15 marca 1948 roku. Był wychowawcą nowicjuszy, przeorem, podprzeorem, definitorem Prowincji, dyskretem klasztoru.

Te rozliczne zajęcia godził z pracą kronikarza Polskiej Prowincji pw. Ducha Świętego i badacza dziejów zakonu. Owocem podejmowanych przez niego poszukiwań była olbrzymia liczba przepisanych lub streszczonych dokumentów naszej historii. Wszystkie te teksty napisał gęsim piórem. Pozostawił po sobie między innymi

10 Liber inscriptionum conven[tus] s[ancti] Michae[lis] Archangeli leopolien[sis] carmelitarum discalceatorum, auspicante R.P. Crescentio a s. Adalberto priore, conficiente P.F. Laurentio a s. Maria - procuratore causarum, authenticus, Anno D-ni 1665, die 20 aprilis, AKPZKB, sygn. AKLW 23, przednia wklejka kopiariusza.

11 Akta personalne o. J.K Osierdy, sygn. PE/O 11; Series Religiosonum Carmelitarum Discalceatomum Provinciae Polonae sub titulo Spiritus Sancti ab anno 1880, sygn. PE 41. 
tłumaczenie $z$ łaciny trzech kronik: klasztoru w Poznaniu ${ }^{12}$, Warszawie ${ }^{13}$ i Wilnie $^{14}$; zapiski dotyczące poszczególnych konwentów w Polsce, na Litwie i Rusi; olbrzymi materiał do biografii karmelitów i karmelitanek bosych. W latach 1928-1939 opublikował też serię artykułów o karmelitańskich klasztorach w periodyku „Głos Karmelu". Na bieżąco pisał i uzupełniał kroniki klasztorów: krakowskiego, lubelskiego i przemyskiego. Chociaż w swej pracy nie stosował wymogów metodologii naukowej, jego spuścizna pozostaje bezcennym materiałem badawczym dla historyków.

\section{O. Benignus Wanat (1934-2013)}

W nowożytnej historii polskich karmelitów bosych największe zasługi dla zachowania dziedzictwa minionych wieków ma o. Benignus Wanat ${ }^{15}$, historyk sztuki, pisarz, twórca archiwum Prowincji i jego pierwszy archiwista.

Józef Wanat urodził się 17 marca 1934 roku we Frydrychowicach, w powiecie wadowickim. Za zgodą rodziców zapisał się w 1948 roku do Małego Seminarium Karmelitów Bosych w Wadowicach. Po ukończeniu trzeciej klasy złożył na ręce o. Anzelma Gądka, prowincjała Polskiej Prowincji Karmelitów Bosych, prośbę o przyjęcie do nowicjatu. Rozpoczął go w czerneńskim klasztorze pw. św. Eliasza 15 lipca 1951 roku. Otrzymał wówczas imię zakonne br. Benignus od Chrystusa Króla. Rok później, 16 lipca 1952 roku, złożył pierwsze śluby. Z Czernej powrócił do Wadowic, aby na przełomie 1952/53 roku dokończyć naukę i przygotować się do egzaminu dojrzałości. Po uzyskaniu matury udał się do Poznania na studia filozoficzne (1953-1955). Po ich zakończeniu przybył do Krakowa, gdzie 15 września 1955 roku złożył profesję uroczystą i rozpoczął studia teologiczne w Wyższym Seminarium Duchowym Karmelitów Bosych (1955-1960). 6 lutego 1959 roku przyjąt święcenia diakonatu, a niespełna cztery miesiące później, 16 maja, święcenia kapłańskie z rąk ks. bpa Karola Wojtyły, w kościele Niepokalanego Poczęcia NMP przy ul. Rakowickiej w Krakowie. Na przełomie 1959/60 roku odbył studium zwane Tirocinium pastorale $\mathrm{u}$ franciszkanów konwentualnych w Krakowie, zalecane przez Stolicę Apostolską. W ramach studium podjął także praktykę duszpasterską w parafii św. Floriana w Krakowie pod kierunkiem jej proboszcza ks. prałata Teofila Kurowskiego.

W roku 1960 o. Anzelm Gądek skierował go na specjalne szkolenia dla kościelnych archiwistów, organizowane na Katolickim Uniwersytecie Lubelskim w związku z podjętymi przez Episkopat Polski przygotowaniami do obchodów milenium chrztu

12 Sygn. AKP 3, Kronika klasztoru poznańskiego OO. Karmelitów Bosych. Przekład z łacińskiego oryginału z uzupełnieniami i objaśnieniami o. Jana Kantego Osierdy.

13 Sygn. AKW 2, Księa fundacji konwentu warszawskiego OO. Karmelitów Bosych. Przekład z łaciny $\mathrm{z}$ uzupełnieniami o. Jana Kantego Osierdy.

14 Sygn. AKO 1, Cronica conventus vilnensis PP. Carmelitarum Discalceatorum.

15 Akta personalne o. B. Wanata, sygn. PE/W 33-34; Conventus et religiosi Provinciae Poloniae, sygn. PE 1 . 
Polski. Decyzja prowincjała szła po linii zainteresowań młodego o. Benignusa, który pytany o swoje hobby wyliczał: historia sztuki, ikonografia maryjna, historia zako$\mathrm{nu}$, archiwistyka i numizmatyka. Na lubelskie zajęcia wyjeżdżał z Czernej w latach 1960, 1961 i 1967. Ich dopełnieniem były eksternistyczne studia historyczne ze specjalizacją w archiwistyce na Wydziale Filozoficzno-Historycznym Uniwersytetu Jagiellońskiego w latach 1964-1969, zakończone uzyskaniem tytułu magistra historii.

W odpowiedzi na apel Episkopatu Polski dotyczący uporządkowania diecezjalnych i zakonnych archiwów Zarząd Prowincji obradujący 22 października 1960 roku w Wadowicach erygował Archiwum Polskiej Prowincji Karmelitów Bosych z siedzibą w Czernej. Jego zorganizowanie zlecił o. Benignusowi, mianując go archiwistą Prowincji. Posługę tę, powierzaną mu przez kolejnych przełożonych prowincjalnych, pełnił przez niemal 52 lata, do 13 maja 2011 roku.

Czas poświęcony na pracę archiwisty - obejmującą starania o odpowiednie pomieszczenie i wyposażenie dla archiwum oraz gromadzenie i opisywanie rozproszonych w różnych klasztorach Prowincji archiwaliów i akt urzędowych - łączył $z$ innymi obowiązkami zakonnymi oraz duszpasterskimi. Nigdy jednak nie traktował archiwistyki jako zajęcia pobocznego. Zdając sobie sprawę z wartości karmelitańskiego dziedzictwa, wkładał w żmudną pracę archiwisty całe serce. Przejął z kancelarii prowincjalnej w Warszawie i biblioteki prowincjalnej w Krakowie zbiory akt wytworzone w latach 1911-1948 oraz liczne rozproszone jednostki archiwalne i dokumentację kancelaryjną z pozostałych klasztorów. Po uporządkowaniu cały zasób podzielił na cztery działy: dokumenty pergaminowe, papierowe i formularzowe; zespoły archiwalne dotyczące poszczególnych klasztorów; spuścizny zakonników; zbiory kartograficzne. Pokłosiem tej pracy był wydany drukiem przez Kurię Krakowskiej Prowincji Karmelitów Bosych w 1998 i 1999 roku dwutomowy „Katalog Krakowskiej Prowincji Karmelitów Bosych w Czernej".

W maju 1966 roku został przeniesiony do Krakowa, gdzie nowy przełożony prowincjalny, o. Otto Filek, powierzył mu obowiązki podprzeora klasztoru i magistra kleryków. Ponownie zwrócił się z prośbą o zwolnienie go z tych urzędów. Decyzję odmowną przyjął w duchu wiary, wypełniając skrupulatnie wszystkie spoczywające nań zadania.

W 1969 roku udał się do Czernej, aby objąć urząd przeora. W kolejnym triennium od 1972 do 1975 roku służył jako przeor wspólnocie lubelskiej, przyjeżdżając do Archiwum w Czernej raz w miesiącu na dwa lub trzy dni. W lipcu 1975 roku wrócił do Krakowa, gdzie pozostał do czerwca 1984, podejmując obowiązki zastępcy przeora, czwartego radnego Prowincji, prefekta studiów Wyższego Seminarium Duchownego, wykładowcy historii Kościoła i zakonu, liturgiki oraz łaciny. Pełnił także posługę spowiednika w kilku zgromadzeniach zakonnych.

W 1976 roku Zarząd Prowincji zlecił o. Benignusowi kierownictwo budowy kaplicy dla św. Rafała Kalinowskiego w Czernej, upoważniając go do zawierania umów 
$\mathrm{z}$ architektami, artystami i rzemieślnikami. Kaplica została ukończona w czerwcu 1983 roku, na kilka dni przed uroczystą beatyfikacją o. Rafała Kalinowskiego i br. Alberta Chmielowskiego na Błoniach Krakowskich przez Ojca świętego Jana Pawła II. W czerwcu 1979 roku definitorium generalne mianowało o. Benignusa archiwistą generalnym zakonu. Odmówił jednak przyjęcia tej funkcji, motywując swoją decyzję słabym zdrowiem i zobowiązaniami podjętymi w Prowincji.

W roku 1981 rozpoczą pod kierunkiem ks. prof. dra hab. Bolesława Przybyszewskiego kurs doktorancki na Papieskim Wydziale Teologicznym w Krakowie. Ukończył go 17 czerwca 1982 roku publiczną obroną rozprawy doktorskiej na temat: „Kult św. Józefa Oblubieńca NMP u Karmelitów Bosych w Krakowie", uzyskując tytuł doktora teologii ze specjalizacją ze sztuki kościelnej. Dwa lata później, 17 marca 1984 roku w pałacu arcybiskupów krakowskich, habilitował się na podstawie rozprawy: "Zakon Karmelitów Bosych w Polsce. Klasztory karmelitów i karmelitanek bosych 1605-1975”. Był to pierwszy przewód habilitacyjny na Wydziale Historii Kościoła Papieskiej Akademii Teologicznej. Prowadził zajęcia dydaktyczne ze sztuki kościelnej w Wyższym Seminarium Duchownym Karmelitów Bosych w Krakowie ina Wydziale Historii Kościoła PAT, gdzie pracował na pół etatu, a od 1993 roku na pełnym etacie. Objął tam kierownictwo katedry sztuki kościelnej. $Z$ wielkim zaangażowaniem popieral powołanie na PAT studium archiwistycznego oraz podyplomowych studiów $\mathrm{z}$ archiwistyki i bibliotekoznawstwa. Był jednym z głównych konsultantów programu kształcenia archiwistów dla specjalności archiwistyka na tej uczelni. Popierał inicjatywę opracowania słownika biograficznego polskich archiwistów kościelnych, który ukazał się w 2017 roku.

Na podstawie uchwały Senatu Papieskiej Akademii Teologicznej w Krakowie z dnia 27 stycznia 1995 roku i wniosku Rady Naukowej Episkopatu Polski Centralna Komisja ds. Tytułu Naukowego i Stopni Naukowych w Warszawie w dniu 30 listopada 1998 roku nadała mu tytuł naukowy profesora nauk teologicznych.

W czerwcu 1984 roku został wybrany prowincjałem. Przeniósł się do siedziby kurii prowincjalnej w Warszawie, dojeżdżając $z$ wykładami do Krakowa co dwa tygodnie. W 1987 roku został ponownie obrany przeorem klasztoru w Czernej, a po zakończeniu triennium w czerwcu 1990 roku po raz drugi prowincjałem Polskiej Prowincji Karmelitów Bosych. Sporo uwagi poświęcił wówczas dziełu przeszczepiania Karmelu terezjańskiego z Polski na Białoruś, Ukrainę i Słowację. Wielkimi krzyżami na drodze jego prowincjalskiej posługi były w tym czasie bolesne wydarzenia związane z konfliktami o klasztor karmelitanek bosych w Oświęcimiu i klasztor karmelitów bosych w Przemyślu. Miłość do zakonu kazała mu w tych trudnych okolicznościach dochodzić słusznych praw swoich sióstr i braci. Miłość do Chrystusowego Kościoła skłaniała go do niełatwego posłuszeństwa decyzjom Stolicy Świętej. Zachęcany po latach do wspomnień o minionych wydarzeniach, mówił o nich z pasją. Widać było, że wciąż nosi Prowincję i jej sprawy w swoim sercu. 
Dekretem Definitorium Generalnego z dnia 6 kwietnia 1993 roku Polska Prowincja pw. Ducha Świętego po przeprowadzonej uprzednio wśród zakonników ankiecie została podzielona na dwie: Prowincję Krakowską i Warszawską. W dniu 21 kwietnia o. Benignus obją urząd komisarza z zadaniem przygotowania Prowincji Krakowskiej do pierwszej w jej historii Kapituły Prowincjalnej, zaplanowanej na czerwiec. W trakcie obrad kapitulnych został wybrany jej pierwszym prowincjałem. Osiadł w domu zakonnym w Krakowie-Prądniku Białym przy ulicy Glogera 5. Po zakończeniu posługi prowincjała pełnił w latach 1996-1999 obowiązki wikariusza prowincjalnego. Od 1999 do 2002 roku służył braciom jako przełożony domu zakonnego w Krakowie-Prądniku Białym. W tych i kolejnych latach był także redaktorem Wydawnictwa Prowincji Krakowskiej, cenzorem, kronikarzem, pierwszym radnym konwentu, członkiem Prowincjalnej Komisji ds. Budownictwa, w dalszym ciagu angażując się w pracę naukową na Papieskiej Akademii Teologicznej i przy Archiwum Prowincji. Bibliografia jego prac naukowych obejmuje około 160 pozycji z zakresu historii sztuki kościelnej i karmelitańskiej, mariologii, józefologii oraz hagiografii.

W 1991 roku, gdy był na urzędzie prowincjała, zdiagnozowano u niego chłoniaka, złośliwy nowotwór w początkowej fazie rozwoju. W Instytucie Onkologicznym w Warszawie stwierdzono, że nie zostało mu więcej niż pięć lat życia. $Z$ takim wyrokiem rozpoczął intensywną pracę, wizytując wspólnoty Prowincji. Udał się także do braci w Burundi i Rwandzie. Podczas Wielkiego Tygodnia w 1996 roku nastąpito powiększenie guzów i wydobycie ich na zewnątrz. Był tak słaby, że nie mógł nawet nakręcić sprężyny budzika ani przekręcić klucza w drzwiach. Został wówczas skierowany na leczenie do Instytutu Onkologicznego w Krakowie. Kolejne dawki „chemii” wyniszczyły jego organizm. Stracił włosy, schudł 20 kilogramów. Swój los zawierzył jednak Matce Bożej i doczekał się Jej interwencji.

Z końcem 2012 roku udał się do Szpitala Uniwersyteckiego w Krakowie przy ul. Śniadeckich 10, gdzie zdiagnozowano u niego obustronne zapalenie płuc. Był bardzo słaby, miał problemy z oddychaniem. Sytuacja powtórzyła się z początkiem następnego roku. Rankiem 26 lutego 2013 roku odprawił w koncelebrze z braćmi Mszę św. i został odwieziony do szpitala. 30 marca, w Wielką Sobotę, uzyskawszy pozwolenie lekarza, przyjechał na kilkudniowy pobyt w klasztorze. Do szpitala miał wrócić w następny czwartek, jednak już we wtorek stan jego zdrowia pogorszył się na tyle, że powrót nastąpił tego dnia wieczorem. Zmarł w szpitalu 9 kwietnia około godziny 22.30. Przyczyną zgonu podaną przez lekarza była niewydolność serca, ostra niewydolność nerek i zatrzymanie krążenia.

Pogrzeb o. Benignusa odbył się 13 kwietnia 2013 roku o godzinie $11.00 \mathrm{w}$ kościele parafialnym Najświętszej Maryi Panny Matki Kościoła w Krakowie-Prądniku Białym. Koncelebrze 88 kapłanów przewodniczył ks. bp Kazimierz Górny, przyjaciel Zmarłego. Homilię wygłosił o. prowincjał Andrzej Ruszała. Msza św. zgromadziła ponadto prawie 100 sióstr zakonnych z różnych zgromadzeń, najbliższą rodzinę 
o. Benignusa oraz licznych jego przyjaciół. Kondukt pogrzebowy na cmentarz parafialny poprowadził na własną prośbę ks. kard. Franciszek Macharski, emerytowany metropolita krakowski.

\section{O. Honorat Gil (1934-2015)}

Kolejnym zasłużonym dla karmelitańskiej archiwistyki był o. Honorat Gii ${ }^{16}$, historyk zakonu, pisarz, kronikarz i archiwista klasztoru w Wadowicach. Urodził się 11 października 1934 roku w Kidałowicach koło Jarosławia na terenie diecezji przemyskiej. Na chrzcie św. otrzymał imię Czesław. W 1941 roku przekroczył progi siedmioklasowej szkoły podstawowej w swej rodzinnej wiosce. Rozpoczętą tam edukację ukończył w Jarosławiu. Tam też zaczął uczęszczać do szkoły średniej, ale niebawem przeniósł się do Niższego Seminarium Karmelitów Bosych w Wadowicach. Wpływ na tę decyzję miała bez wątpienia jego ciotka, karmelitanka bosa z przemyskiego klasztoru, s. Bronisława Lotycz.

W 1951 roku wstąpił do nowicjatu karmelitów bosych w Czernej, gdzie 15 lipca otrzymał habit zakonny i nowe imię: brat Honorat od św. Naszej Matki Teresy. Rok później, 16 lipca, złożył pierwsze śluby. Z Czernej powrócił do Wadowic, aby na przełomie 1952/53 roku dokończyć naukę w liceum. Udał się następnie do Poznania na studia filozoficzne (1953-1955). Po ich zakończeniu przybył do Krakowa, gdzie 8 grudnia 1955 roku złożył profesję uroczystą i rozpoczął studia teologiczne w Wyższym Seminarium Duchowym Karmelitów Bosych (1955-1959). Nie odznaczał się żelaznym zdrowiem. Już jako kleryk leczył się na gruźlicę. Pozostałości tej choroby dawały o sobie znać przez całe jego zakonne życie. Znosił to cierpliwie i bez narzekania.

16 maja 1959 roku przyjąt święcenia kapłańskie, a trzy dni wcześniej, 13 maja, zdał egzamin dojrzałości w Korespondencyjnym Liceum Ogólnokształcącym w Krakowie. Widząc potencjał intelektualny o. Honorata oraz jego zainteresowanie historią, przełożeni pozytywnie odpowiedzieli na jego prośbę dotyczącą możliwości dalszych studiów. Rozpoczą je niebawem po święceniach kapłańskich na Wydziale Teologicznym Katolickiego Uniwersytetu Lubelskiego, w ramach sekcji historii Kościoła. 24 stycznia 1962 roku uzyskał tam dyplom magistra, przedstawiając pracę magisterską na temat „Początki Zakonu Karmelitów Bosych w Polsce”, a 7 czerwca 1968 roku dyplom doktora historii Kościoła na podstawie pracy „Prowincja Polska Zakonu Karmelitów Bosych w latach 1617-1655”. 26 stycznia 1967 roku uzyskał tytuł magistra historii na Wydziale Filozoficznym Uniwersytetu Jagiellońskiego po studiach eksternistycznych II stopnia.

Pracę naukową łączył z pracą wykładowcy. W latach 1962-1987 był nauczycielem historii i geografii w Niższym Seminarium Karmelitów Bosych w Wadowicach. Od 1963 roku aż do początku lat 90. wykładał także historię Kościoła w Wyższym

16 Akta personalne o. Cz. Gila, sygn. PE/G 63-64; Conventus et religiosi Provinciae Poloniae, sygn. PE 1. 
Seminarium Karmelitów Bosych w Krakowie. Prowadził jednocześnie seminarium naukowe z tego przedmiotu. Zwieńczeniem naukowej drogi był stopień doktora habilitowanego historii Kościoła w zakresie historii Kościoła czasów najnowszych uzyskany na Papieskiej Akademii Teologicznej w Krakowie w dniu 8 maja 1991 roku.

Badania $z$ dziedziny historii Zakonu Karmelitów Bosych w Polsce wymagały od o. Honorata rzetelnej kwerendy w kilku zagranicznych archiwach. Najpierw udał się do Rzymu, gdzie na przełomie 1970/71 roku spędził sporo czasu w archiwum generalnym zakonu oraz $w$ archiwum watykańskim. W 1979 roku podobną kwerendę przeprowadził w archiwum Prowincji Austriackiej w Wiedniu, a w $1980 \mathrm{w}$ archiwum klasztoru karmelitów bosych w Munster koło Chicago. Dobrym przygotowaniem do tego typu zajęć był odbyty przez niego jeszcze w 1961 roku kurs dla archiwistów kościelnych zorganizowany przez Ośrodek Archiwów, Bibliotek i Muzeów Kościelnych na KUL-u. Uczęszczał na tamtejsze wykłady razem z o. Benignusem Wanatem.

We wrześniu 1980 roku uczestniczył czynnie w Międzynarodowym Kongresie Józefologicznym w Montrealu, a w 1986 roku w Kongresie Mariologicznym w Lublinie. Jego referat został odczytany na Międzynarodowym Kongresie Mariologicznym w Kevelear. W 1990 roku uczestniczył w Krajowym Kongresie Mariologicznym w Częstochowie. Współpracował z Instytutem Geografii Historycznej Kościoła przy KUL-u oraz redakcją Encyklopedii katolickiej. Bibliografia jego prac naukowych obejmuje ponad 110 pozycji z zakresu historii Kościoła i zakonu, mariologii, józefologii oraz hagiografii, nie licząc popularnych artykułów publikowanych w lokalnej prasie parafialnej.

Oprócz pracy naukowo-dydaktycznej podejmował też inne obowiązki poruczone mu przez przełożonych. Był najpierw drugim (1984-1987), a później czwartym radnym Prowincji (1990-1994). Łączył tę funkcję z posługą prowincjalnego prefekta studiów. W późniejszych latach doszły także obowiązki wicepostulatora spraw kanonizacyjnych, pierwszego radnego wspólnoty w Wadowicach (gdzie przebywał od 1962 roku aż do śmierci), archiwisty i kronikarza wspólnoty, sekretarza kapituły konwentualnej, redaktora oraz cenzora w Wydawnictwie Karmelitów Bosych w Krakowie.

Szczególnie piękną kartą jego karmelitańskiej i naukowej posługi była współpraca z postulacją generalną zakonu w procesie beatyfikacyjnym i kanonizacyjnym św. Rafała Kalinowskiego. $Z$ czasem stał się niezmordowanym propagatorem kultu tego świętego zakonnika. Wydał jego pisma oraz naukową biografię przetłumaczoną na kilka języków. Był także wicepostulatorem w procesie beatyfikacyjnym o. Alfonsa Mazurka, a ponadto prezesem komisji historycznej w procesie m. Teresy Marchockiej. Każdej z tych postaci poświęcił sporo opracowań hagiograficznych.

Pracował niemal do ostatnich miesięcy życia. Zmarł w klasztorze w wieku 80 lat, 12 września 2015 roku około godziny 16.40, w swoim ulubionym fotelu. Pogrzeb odbył się 15 września. Mszy św. koncelebrowanej przez ponad 50 kapłanów przewodniczył o. prowincjał Tadeusz Florek. Ciało złożono na wadowickim cmentarzu. 


\section{O. Kajetan Furmanik (1929-1990)}

Obok wymienionych wyżej osób warto jeszcze wspomnieć o. Kajetana Furmani$\mathrm{ka}^{17}$. Chociaż z wykształcenia nie był ani historykiem, ani archiwistą, to jednak obydwie te dziedziny nauki stanowiły pole jego osobistych zainteresowań, szczególnie historia zakonu. Jego ponaddwudziestoletniej pracy nad materiałami źródłowymi wypożyczonymi z Archiwum Prowincji zawdzięczamy czterotomową „Księgę zmarłych karmelitów bosych w Polsce, na Litwie i Rusi 1607-1998"18, wydaną drukiem w Krakowie w 2002 roku przez Kurię Krakowskiej Prowincji Karmelitów Bosych. Obejmuje ona 1556 biogramów.

Jerzy Furmanik urodził się 16 kwietnia 1929 roku w Paczółtowicach w diecezji krakowskiej. Habit zakonny przyjął w Czernej 24 lipca 1948 roku wraz z zakonnym imieniem br. Kajetan od Najświętszego Serca Jezusa. Profesję uroczystą złożył 28 lipca 1952 roku, a święcenia prezbiteratu przyjął 14 lipca 1957. Przez wiele lat był wychowawcą nowicjuszy na urzędzie magistra nowicjatu i pierwszego radnego klasztoru w Czernej (1960-1969, 1981-1984) i w Piotrkowicach (1984-1987). Pełnił też urząd przeora konwentu w Wadowicach (1969-1972) i w Czernej (1975-1979). Ponadto w latach 1972-1981 pełnił urząd wizytatora Świeckiego Zakonu Karmelitów Bosych w Polsce. Zmarł w Krakowie 24 kwietnia 1990 roku.

W pracy badawczej nad historią polskich karmelitów bosych współpracował $\mathrm{z}$ archiwistą Prowincji o. Benignusem Wanatem, który po latach wspominał:

Jego hobby ulubione to historia zakonu, a szczególnie Polskiej Prowincji Ducha Świętego. Wszystkie wolne chwile poświęcał gromadzeniu wiadomości z tej dziedziny. Już w czasie studiów teologicznych w Krakowie w latach 1955-1958 miałem okazję podejmować $z$ nim częste rozmowy na interesujące nas zagadnienia. Owocem wzajemnego zainteresowania historią zakonu były krótkie komunikaty i artykuły w seminaryjnym czasopiśmie Juventus Teresian ${ }^{19}$. W czasie naszych spotkań ułożyliśmy sobie ambitny plan pracy na przyszłość. Podzieliliśmy się zagadnieniami. O. Kajetan miał opracować biogramy wszystkich karmelitów bosych w Polsce, a ja ukierunkowałem się na opracowanie poszczególnych klasztorów na tle ogólnego zarysu Prowincji. W tych kierunkach przeprowadzane były kwerendy archiwalne i biblioteczne w kraju i za granicą. Późniejsze nasze kontakty dotyczyły już konkretnej i bliskiej współpracy. (...) Praca o. Kajetana pomimo braku warsztatu naukowego ma ogromną wartość i znaczenie dla naszego zakonu. Podaje sprawdzone informacje biograficzne, a w znacznej mierze pełne

17 Akta personalne o. K. Furmanika, sygn. PE/F 14; Conventus et religiosi Provinciae Poloniae, sygn. PE 1.

18 Po śmierci o. Furmanika publikacja została poszerzona o biogramy zakonników zmarłych do 1998 roku.

19 "Juventus Teresiana" - czasopismo Studendatu Karmelitów Bosych w Krakowie. Wychodziło w latach 1956-1959, ukazało się 14 numerów. 
curricula vitae poszczególnych zakonników. Ukazuje budujące przykłady wierności charyzmatów podejmowanych prac i działalności duszpasterskich, oświatowych dla dobra Kościoła i zakonu oraz podaje wiele wydarzeń z życia Prowincji. Opracowanie życiorysów $w$ formie popularnej podyk towane było ich przeznaczeniem do czytania $w$ refektarzu wszystkim braciom $w$ przypadające rocznice śmierci poszczególnych zakonników ${ }^{20}$.

\section{Metoda zastosowana przez o. Benignusa Wanata}

Uczestnicząc w wykładach $\mathrm{z}$ archiwistyki na KUL-u, o. Benignus zetknął się po raz pierwszy $z$ profesjonalnym podejściem do średniowiecznego dziedzictwa pisanego. Zajęcia prowadzone przez polskich specjalistów - między innymi doc. W. Budkę, prof. Z. Budkę, doc. B. Kürbis, dr S. Sawicką, dra J. Woronczaka, dra H. Kowalewicza, doc. J. Karwińską, doc. J. Zatheya i dra J. Lewańskiego - obejmowały następujące tematy: materiał rękopisów, chronologia średniowiecza, paleografia łacińska, oprawa rękopisów średniowiecznych, adnotacje muzyczne rękopisów, średniowieczne rękopisy biblijne, liturgiczne i homiletyczne, konserwacja rękopisów średniowiecznych, średniowieczne rękopisy hagiograficzne, historyczne, filozoficzne i prawne ${ }^{21}$.

Z KUL-owskich wykładów o. Benignus wyniósł nie tylko historyczną wiedzę o średniowiecznym piśmiennictwie, ale także umiejętność fachowego opisywania i katalogowania karmelitańskiego dziedzictwa. Zgodnie z przyjętymi kanonami, które obowiązują w archiwistyce do dzisiaj, każdą jednostkę w powstającym w Czernej Archiwum Prowincji opisywał według następującego schematu: nazwa zespołu, sygnatura, tytuł jednostki, daty skrajne jednostki, język, opis zewnętrzny, liczba kart/ stron, uwagi, informacje o dostępnych mikrofilmach, skanach jednostki lub inne informacje o niej. Korzystał także z instrukcji dra K. Kaczmarczyka, dr J. Karwasińskiej i dra A. Wolffa: Opracowanie dokumentów pergaminowych i papierowych archiwum ${ }^{22}$, a opisując pieczęcie widniejące na dokumentach, wzorował się na zasadach sfragistyki podanych w publikacji M. Gumowskiego, M. Haisiga i S. Mikuckiego Sfragistyka ${ }^{23}$.

\section{ZBIORY POLSKIEGO ARCHIWUM}

Po przeprowadzeniu centralizacji akt $z$ kancelarii urzędu prowincjała $z$ Krakowa i Warszawy oraz z innych klasztorów, po uporządkowaniu i scaleniu zespołów we-

20 K. Furmanik, Księga zmarlych ojców i braci karmelitów bosych Prowincji Polskiej i Prowincji Krakowskiej pw. Ducha Świętego 1881-1998, Kuria Krakowskiej Prowincji Karmelitów Bosych, Kraków 1998, s. 5-6.

21 Plan wykładów na KUL-u w 1960 r. Akta personalne o. B. Wanata, sygn. PE/W 33, k. 22.

22 „Archeion” $19-20(1951)$, s. 139-177.

23 Warszawa 1960 
dług właściwych registratur, cały zasób podzielony został przez o. Benignusa na cztery działy: I. Dokumenty, II. Zespoły archiwalne, III. Zbiory i spuścizny zakonników (rękopisy), IV. Kartografia. Po jego śmierci uzupełniono w latach 2012-2018 dział drugi (doszły też nowe sygnatury) i utworzono kolejne: $V$. Zbiory fotografii karmelitańskich, VI. Zbiór karmelitańskich tłoków pieczętnych, VII. Zbiór rozmaitości.

\section{Dokumenty}

W dziale tym o sygnaturze DK, obejmującym 148 jednostek, wyodrębniono trzy kategorie dokumentów: pergaminowe, papierowe i formularzowe, czyli blankietowe.

\section{Zespoły archiwalne}

Dział obejmuje dokumentację poszczególnych klasztorów karmelitów bosych i karmelitanek bosych, trzewiczkowych oraz innych instytucji. Zespoły otrzymały następujące sygnatury:

$\mathrm{AGK}=$ Archeologia Góry Karmel,

$\mathrm{AKB}=$ Archiwum klasztoru w Berdyczowie,

$\mathrm{AKBW}=$ Archiwum klasztoru karmelitanek bosych $\mathrm{w}$ Wilnie,

$\mathrm{AKC}=$ Archiwum klasztoru w Czernej,

$\mathrm{AKD}=$ Archiwum klasztoru karmelitanek trzewiczkowych $w$ Dubnie,

$\mathrm{AKG}=$ Archiwum klasztoru w Gudohajach,

AKGE = Archiwum klasztoru w Głębokiem,

AKGR $=$ Archiwum klasztoru $w$ Grodnie,

AKK $=$ Archiwum klasztoru $w$ Kluszkowcach,

AKKŁ $=$ Archiwum karmelitanek bosych $w$ Krakowie na Łobzowie,

AKKW = Archiwum karmelitanek bosych $w$ Krakowie na Wesołej,

$\mathrm{AKL}=$ Archiwum klasztoru w Lublinie,

AKLW = Archiwum klasztoru we Lwowie,

AKŁ $=$ Archiwum klasztoru w Łodzi,

$\mathrm{AKM}=$ Archiwum klasztoru $\mathrm{w}$ Miadziole,

AKML $=$ Archiwum klasztoru w Milatynie,

$\mathrm{AKMU}=$ Archiwum klasztoru w Munster (USA),

$\mathrm{AKO}=$ Archiwum klasztoru Ostrobramskiego w Wilnie,

$\mathrm{AKP}=$ Archiwum klasztoru $w$ Poznaniu,

AKPI = Archiwum klasztoru w Piotrkowicach,

$\mathrm{AKPR}=$ Archiwum klasztoru $\mathrm{w}$ Przemyślu,

AKW $=$ Archiwum klasztoru $w$ Warszawie,

AKWC $=$ Archiwum klasztoru $w$ Wiśniowcu, 
AKWD $=$ Archiwum klasztoru $w$ Wadowicach (1),

AKWE $=$ Archiwum klasztoru $w$ Wadowicach (2),

AKWI $=$ Archiwum klasztoru w Wiśniczu,

AKWR $=$ Archiwum klasztoru we Wrocławiu,

$\mathrm{AKZ}=$ Archiwum klasztoru $\mathrm{w}$ Zagórzu,

AKZI $=$ Archiwum klasztoru $w$ Zawoi,

$\mathrm{AKZO}=$ Archiwum klasztoru $w$ Zakrzewie,

AMBR = Archiwum Wikariatu Regionalnego Burundi-Rwanda,

AMK = Archiwum klasztoru św.św. Michała i Józefa w Krakowie,

ANPK = Archiwum klasztoru Niepokalanego Poczęcia NMP w Krakowie,

APGW = Archiwum Prywatnego Gimnazjum $w$ Wadowicach,

AŚRK = Archiwum św. Rafała Kalinowskiego,

KAKC $=$ Kartografia klasztoru $w$ Czernej,

OCDS $=$ Archiwum Świeckiego Zakonu Karmelitów Bosych,

$\mathrm{PE}=$ Akta personalne zakonników,

$\mathrm{UKCH}=$ Akta klasztoru $w$ Charkowie,

$\mathrm{UKK}=$ Akta klasztoru $\mathrm{w}$ Kijowie.

\section{Zbiory i spuścizny zakonników (rękopisy)}

Dział o sygnaturze RKPS gromadzi pamiątki po zmarłych zakonnikach. Tematycznie jest różnorodny: od korespondencji, przez kazania i artykuły naukowe, po poezję $i$ albumy fotograficzne.

\section{Kartografia}

Dział ten o sygnaturze A obejmuje kolekcję 13 atlasów z XVI, XVII i XVIII wieku.

\section{Zbiory fotografii karmelitańskich}

W skład tego działu wchodzą następujące zespoły:

AKWE 266-278 = Fotografie klasztoru w Wadowicach,

$\mathrm{FAKO}=$ Fotografie klasztoru $w$ Wilnie,

FAKP $=$ Fotografie klasztoru $\mathrm{w}$ Poznaniu,

FKC $=$ Fotografie klasztoru w Czernej,

FKGL $=$ Fotografie klasztoru $w$ Głębokiem,

FKGR $=$ Fotografie klasztoru $w$ Grodnie,

FKK $=$ Fotografie klasztoru $w$ Kluszkowcach,

FKL $=$ Fotografie klasztoru $w$ Lublinie,

FKLW = Fotografie klasztoru we Lwowie-Persenkówce, 
FKŁ $=$ Fotografie klasztoru $w$ Łodzi,

FKM $=$ Fotografie klasztoru $w$ Miadziole,

FKPD $=$ Fotografie klasztoru $w$ Kamieńcu Podolskim,

FKPI $=$ Fotografie klasztoru $w$ Piotrkowicach,

FKPR $=$ Fotografie klasztoru w Przemyślu,

FKW $=$ Fotografie klasztoru $w$ Warszawie,

FKWC $=$ Fotografie klasztoru $w$ Wiśniowcu,

FKWI = Fotografie klasztoru $w$ Wiśniczu,

FKWR $=$ Fotografie klasztoru we Wrocławiu,

FKZ = Fotografie klasztoru w Zagórzu,

FKZI = Fotografie klasztoru $w$ Zawoi,

FNKP $=$ Fotografie klasztoru $w$ Krakowie: Niepokalane Poczęcie NMP,

FRK = Fotografie związane $z$ osobą św. Rafała Kalinowskiego.

W archiwum znajduje się także duża kolekcja różnego typu klisz fotograficznych.

\section{Zbiór karmelitańskich tłoków pieczętnych}

Zbiór o sygnaturze KTP obejmuje ponad 200 jednostek różnego typu tłoków: metalowych, gumowych i z tworzyw współczesnych.

\section{Zbiór rozmaitości}

W skład tego zbioru wchodzą między innymi: ZGD = Zbiór grafiki dawnej, FRS $=$ Fragmenty rękopisów średniowiecznych, $\mathrm{PAM}=$ Patron miesięczny, $\mathrm{PM}=$ Pocztówki o tematyce militarnej z lat 1914-1920. Pierwsza wojna światowa i wojna polsko-bolszewicka. Ponadto zebrano i zabezpieczono bogatą kolekcję medalików i medalionów o tematyce religijnej i świeckiej.

\section{Przeniesienie archiwum do Krakowa}

Podczas wizytacji generalskiej o. Saverio Cannistry w 2012 roku została podjęta decyzja o przeniesieniu Archiwum Prowincji z Czernej do krakowskiego klasztoru przy ul. Zygmunta Glogera 5. Stały za nią następujące motywy. Po pierwsze, lokalizacja archiwum. Pomieszczenie do składowania archiwaliów w Czernej było bardzo małe i zawilgocone, co znacznie odbiło się na stanie zbiorów. Pomimo oddanej pracy o. Benignusa dokumenty nie mogły w tamtym czasie uzyskać lepszych warunków przechowywania. Po drugie, braki w zbiorach. Lokalizacja archiwum w Czernej i pobyt archiwisty w domu zakonnym przy ul. Zygmunta Glogera już za czasów o. Benignusa doprowadziły do nieuprawnionego wchodzenia osób trzecich do pomieszczeń archiwum. W konsekwencji zaistniały pewne braki w zgromadzonym tam zbiorze. 
Po trzecie, korzystanie ze zbiorów. Udostępnianie archiwaliów osobom spoza Krakowa bardzo często wiązało się z koniecznością organizowania im wyjazdu do Czernej.

Przenoszenie zbiorów do nowej lokalizacji trwało ponad rok. Dokumenty przewoził osobiście archiwista Prowincji niewielkimi partiami, aby nie pomieszać układu, jaki tworzyły na półkach w Czernej. Przy okazji dokonano inwentaryzacji archiwaliów, by po 50 latach istnienia archiwum w Czernej ustalić faktyczny ich stan. Dokonano także oczyszczenia zbioru z zalegającego kurzu i licznych drobnych reparacji. Z ekonomatu Prowincji zostały natomiast przekazane stosowne fundusze, dzięki którym na przestrzeni kilku lat można było zakupić pudła archiwizacyjne do przechowywania dokumentów oraz inne akcesoria niezbędne we współczesnych archiwach.

\section{WYBRANA BIBLIOGRAFIA}

Dicta. Zbiór łacińskich sentencji, przystów, zwrotów, powiedzeń, red. Cz. Michalunio, Kraków 2010.

Instructiones Fratrum Discalceatorum Congregationis S. Eliae Ordinis Beatissimae Virginis Mariae de Monte Carmelo, Romae 1635.

MazureK A., Kronika własna. Część V z lat 1930-1944, AKPZKB (Archiwum Krakowskiej Prowincji Zakonu Karmelitów Bosych), sygn. AAM 7.

Kronika klasztoru OO. Karmelitów Bosych w Czerny z lat 1938-1953, AKPZKB, sygn. AKC 6.

Wanat B., Katalog Archiwum Krakowskiej Prowincji Karmelitów Bosych pw. Ducha Świętego w Czernej, Kuria Krakowskiej Prowincji Karmelitów Bosych, t. 1, Kraków 1998, t. 2, Kraków 1999.

GiL Cz., Karmelita - Homo viator w XVII i XVIII w., „Nasza Przeszłość” 109 (2008). FurmantK K., Ksiega zmartych karmelitów bosych w Polsce, na Litwie i Rusi 1607-1998, t. I/1-2, Kuria Krakowskiej Prowincji Karmelitów Bosych, Kraków 2002.

Liber inscriptionum conven[tus] s[ancti] Michae[lis] Archangeli leopolien[sis] carmelitarum discalceatorum, auspicante R.P. Crescentio a s. Adalberto priore, conficiente P.F. Laurentio a s. Maria - procuratore causarum, authenticus, Anno D-ni 1665, die 20 aprilis, AKPZKB, sygn. AKLW 23.

Akta personalne o. J.K. Osierdy, AKPZKB, sygn. PE/O 11.

Akta personalne o. B. Wanata, AKPZKB, sygn. PE/W 33-34.

Akta personalne o. Cz. Gila, AKPZKB, sygn. PE/G 63-64.

Akta personalne 0 . K. Furmanika, AKPZKB, sygn. PE/F 14. 


\section{ABSTRACT \\ JERZY ZIELIŃSKI, OCD \\ The Polish Archives of the Discalced Carmelites: History, Outstanding Figures, Method and Collections}

In accordance with the old custom of monasteries, important documents, books and precious objects were assembled in arca trium clavium - a three-key chest. It served as a home archive. The $16^{\text {th }}$ and the $17^{\text {th }}$ centuries were not very good periods for the Carmelite archives. Most of the Discalced Carmelite monasteries were founded in the eastern territories of the Polish Commonwealth, which were lost as the result of numerous wars. However, over the centuries there were plenty of friars who undertook an effort to collect and describe archival materials. They were Fr Wawrzyniec of the Blessed Virgin Mary (d. 1682), Fr Jan Kanty Osierda (1878-1948), Fr Benignus Wanat (1934-2013), Fr Honorat Gil (1934-2015) and Fr Kajetan Furmanik (1929-1990). The contemporary archives of the Polish Discalced Carmelites were organised and ordered by Fr Wanat. According to the canon, which is binding in archival science, he described each unit in the Archives of the Province of Czerna adopting the following scheme: team name, reference number, unit title, earliest and latest dates, language, external description, number of cards/pages, notes, information about available microfilms, scans or extra information about the unit. In 2012, the archives of the Province were moved from the monastery in Czerna to the monastery in Kraków, at 5 Zygmunta Glogera Street.

Keywords: archive, archival studies, archival materials, Discalced Carmelite, Osierda, Wanat, Gil, Furmanik

Słowa klucze: archiwum, archiwistyka, archiwalia, karmelici bosi, Osierda, Wanat, Gil, Furmanik 